\title{
The Competence of Teaching Training Program Students in Devising Integrated Lesson Plan and Islamic Value in Biology Lesson
}

\author{
Listyono $^{1}$, Kasmadi Imam Supardi ${ }^{2}$, Saeful Ridlo ${ }^{3}$, Wiyanto ${ }^{4}$ \\ ${ }_{1,2,3,4}$ Graduate School, Universitas Negeri Semarang, Indonesia \\ Coresponding email: listyono@walisongo.ac.id
}

\begin{abstract}
One of the purposes of learning with scientific approach on the curriculum of 2013 is to develop the character of the students. Learning science may mean building morality and characters of the students in order to have more knowledge about themselves and the God they believe in. The glorious Qur'an and Hadith as literacy are the primary source of truth, because they are a collection of revelations which are conserved and properly sourced from the God himself. Biology is part of science literacy resource that has the value of nature as kauniyah verse and the Holy Qur'an as a qauliyah verse. Integrating Islamic values in the lesson plan will facilitate teachers to instill character building, because Islamic values can be implemented at every step of the study. This research develops the design biology lesson planning courses that integrates the Islam values with scientific approach on 67 students of integrated Islamic and biology teaching training program. The research used descriptive quantitative method with scale of 67-111.6 is incompetent, while 111.7-156.2 is competent enough and 156.3-201 is competent. The results of this study show the competence of the students to achieve the indicator in devising the lesson plan: a) formulate indicators: 192.8, b) formulate learning objectives: 189.3, c) selection of teaching materials: 198.4, d) selection of learning resources: e) selection of learning media: 193.5, f) selection of learning models: 199.5, g) selection of learning methods: 199,7, h) preparation of learning scenarios that integrating Islamic values according to scientific approach: 196.8; i) designing assessment: 176.2. The average student ability of 193.6 can be categorized as competent.
\end{abstract}

Keywords: Learning plan, Islamic character values

\section{Introduction}

The purpose of learning is to improve knowledge, skills, strategies, beliefs, behavior and character of people. The actualization of Islamic values is considered as an important effort to build and instill ideology as a way of life since the development of human character in Islam is largely a process of absorbing one's desire towards values (Huda, M., 2012). Value is a person's belief in behaving in daily life according to his choice. The value of religion is a person's action and thought based on his religious beliefs (Winter, D.G., 2010).

Qur'an and hadith function as a basic value in daily behaviors and thinking because they are believed to be gift and guidance from Allah SWT (the almighty God and most worthy of praise) to survive in the life of the world and the hereafter for Muslims. As the main source and reference of faith, the guidelines of life, Quran and hadith are believed to be true form the characteristics of being a good person and contain learning elements for all human beings. "O people! There comes to you a direction from your Lord and healing for (sickness) in your heart, and for those who believe, a guidance and grace" (The Holy Quran, 2013).

The values in Qur'an and the Hadith are not only related to the worship, society, and way of life of Islamic society, but we can also learn the value of science, and the truth is guaranteed. The value of knowledge in the Qur'an is a concept of Islamization of science (Guessoum, N., 2008). On the other hand, the values in the Qur'an can be a source of literacy for the Muslim community and the world of science (Rehaf. A.M., 2016).

Teaching the values of Islam can be integrated with all fields of science. One of those is biology. Thus, it is necessary for teacher candidates to have skills to integrate the value of Islam in their Lesson plans. The role of teacher candidates in learning begins with lesson planning in accordance with the goals set before (Yeung, C.L., 2016). Competence, personality, and religious behaviour also needed to be possessed by teachers to transfer the values to their students.

There are several principles in teaching character that are: 1) ethical values as the core basis of character, 2) encompasses thoughts, feelings, and behaviors, 3) proactive and comprehensive approach of core values of characters in the school life phase, 4) school community awareness, 5) behaviour habituation in the action and moral of students, 6) integrating academic and curriculum activities that aimed at students success in future, 7) 
developing students' intrinsic motivation, 8) community participation, 9) good school leadership, 10) involvement of parents and community members as partners in character building efforts, 11) character education evaluations must involve all the school staffs as character-teaching, to embody students' good character (Lickona, T., 2009).

Lectures that teach how to integrate Islamic values in the planning of teaching biology is an alternative to prepare prospective teachers in teaching characters. In Islamic universities this is related to the vision of institutions, namely how the concept of integrating between the values in the Qur'an and Hadith with science including in biology.

The purpose of this study is to analyze the ability of biology teacher candidates in preparing lesson plan that related to the implementation of integrated biology and Islamic values. All the biology teacher candidates in this research have taken course and passed the lecture of biology lesson planning that integrated biology and Islamic values. In this lecture, the students are taught to understand the planning of teaching biology, covering the concept of teaching in Islam, designing the teaching planning, the concept of integration of Islamic values and science and how the method of inculcating the value of Islam with the materials of biology. At the end of the course the students is taught to plan the implementation of integrating biology and the Islamic values.

\section{Methods}

This research refers to research and development. The data of the research is combined comprehensively and synergistically and analyzed serially and partially referring to Mixed Method Research (Creswell, J.W. \& Clark, V.L.P., 2007). Respondents in this study were biology teacher candidates at the biology education program of Walisongo State Islamic University of Semarang taking the course of biology lesson planning. There were 67 biology teacher candidates who took the lecture. They have taken religious subjects (Ulum al Qur'an, Ulum al Hadith, Islamic Studies, Intensive Religion Learning, Hadith, Islamic Education, Tafsir, Tahfid, Akhlaq Tasawuf) and biology pedagogy lesson as well as Islamic pedagogy lesson (learning methodology, science education, learning psychology, integration of science, technology and Islam, curriculum, learning evaluation, learning media). During the research, the students were taking the course of Biology Lesson Planning with 2 credits.

The data of students' ability was analyzed in descriptive-quantitative and qualitative ways. Skills analyzed included the ability to integrate the value of Islam in biology materials in the form of portfolios, and the ability to develop the implementation of biology lesson plan that integrates the the Islamic value (the value of Qur'ran and Hadith) with a scientific approach. The flow of integration of Islamic values is presented in the following figure.

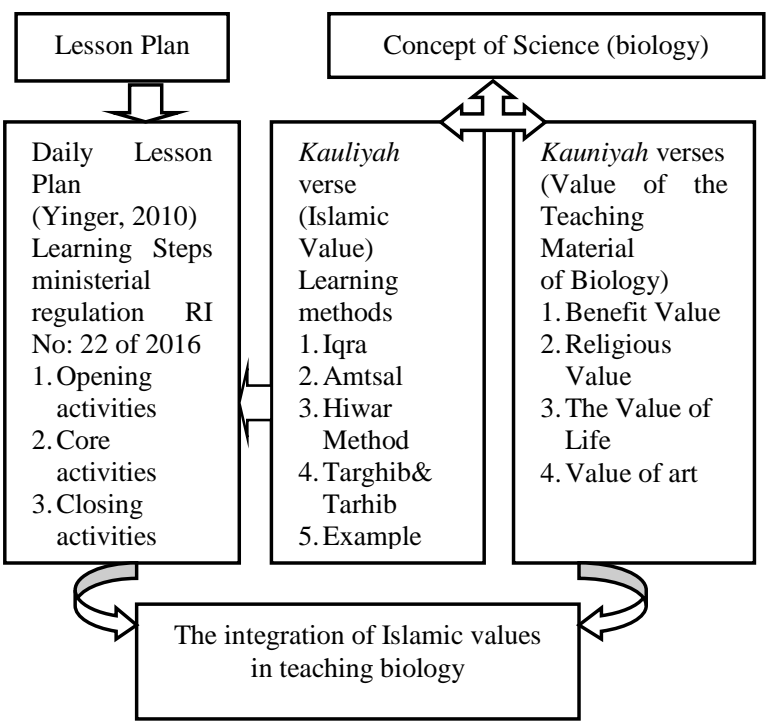

Figure 1. The concept of integrating to Islamic values into the learning steps (Listyono, 2018)

The concept of measuring the ability of the teacher candidates in preparing the lesson plan is displayed as follows.

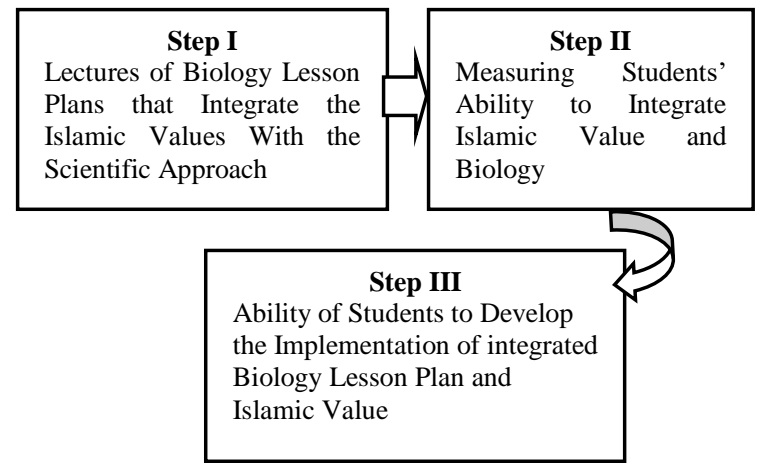

Figure 2. The ability of teacher candidates to prepare lesson plans

The average criteria for students' ability to integrate Islamic values on biology learning materials can be describe into several categories: 67-111.6 categorized as incapable, 111.7-156.2 
categorized as capable enough, 156.3-201 categorized as capable. The average criteria of the teacher candidate students' ability to formulate a lesson plan for implementing biology that integrate Islamic values with scientific approaches can be categorized into some points: 67-111.6 categorized as incapable, 111.7-156.2 categorized as capable enough, 156.3-201 categorized as capable (Hadjar, I., 2014).

\section{Results and Discussion}

\subsection{Lesson planning}

Lesson planning is an activity of setting learning objectives, preparing of teaching materials, learning resources, and also selecting suitable media (Ray, I., \& Chris B., 2008), selecting of approaches, learning strategies, arranging class environment, designing learning score and outcomes as an assessment system and designing learning procedures in order to guide learners in order to optimize the learning process to develop the all three domains, cognitive, affective and psychomotor in the form of learning scenarios according to the learning approach used (Husamah \& Yuni P., 2014).

In planning all the learning process, one needs to master the theory of learning descriptively. There are four cycles of planning the lesson, which are annual planning, term planning, unit planning and daily planning (Permendiknas, No: 22., 2016). The implementation of daily teaching consists of preliminary, core and closing (Reigeluth $\mathrm{C} \mathrm{M}$. 2009). The preliminary stage contains motivation, opinion, as well as exploring the initial knowledge of the students. The core activity is related to the formulation of problems, observation and data collection and also problem-solving. Closing activity is related to making a summary of the lesson, reflections on activities that already implemented and reflecting students' feedback towards learning outcomes and evaluation (Sarah Q., 2010).

Character education requires multiple approaches and methods comprehensive. The contents must be comprehensive, covering all issues relating to the choice of personal values regarding ethics in general. Includes value inclusion, exemplary giving, so that it can be independent by teaching and facilitating responsible moral decision making and various life skills (soft skills), both in the education process inside and outside the classroom (Saeful, R., 2012).
Learning based on Islamic values can affect students' ability to understand the integration of Islamic values (Rochman, C., 2010). The ability to integrate Islamic values in science learning can be a means of building morality and characters of students to have more knowledge about themselves and the God they trust to (K.I. Supardi, 2017). The moral character and message of Islamic values (Koran and Hadith) can be integrated in teaching biology (Listyono, 2018).

3.2 Technical integration of Islamic values at learning stage

Technical integration of Islamic values is a stage in integrating Islamic values to teaching plans. The stage uses a scientific approach and learning sequence (Yinger 2010). The steps of student activities and teaching methods and the method of instilling Islamic values are the focus of attention. Technical integration of Islamic values can be explained in table 1 below.

Table 1. The Value Technical Integration in Learning Stage (Listyono, 2018)

\begin{tabular}{|c|c|c|c|}
\hline $\begin{array}{l}\text { Learning } \\
\text { Steps }\end{array}$ & Learning stage & Learning activities & $\begin{array}{l}\text { The method } \\
\text { integration } \\
\text { of Islamic } \\
\text { values }\end{array}$ \\
\hline $\begin{array}{l}\text { Learning } \\
\text { Steps }\end{array}$ & Learning stage & Learning activities & $\begin{array}{l}\text { The method } \\
\text { integration } \\
\text { of Islamic } \\
\text { values }\end{array}$ \\
\hline Opening & $\begin{array}{l}\text { Preliminary } \\
\text { Motivation } \\
\text { Apperception } \\
\text { Student } \\
\text { opinion }\end{array}$ & $\begin{array}{l}\text { Demonstrating, } \\
\text { story events, } \\
\text { observing } \\
\text { phenomena, } \\
\text { questioning }\end{array}$ & $\begin{array}{l}\text { Hiwar, Iqra, } \\
\text { amtsal }\end{array}$ \\
\hline Core & $\begin{array}{l}\text { Problem } \\
\text { formulation, } \\
\text { Data collection } \\
\text { Data analysis, } \\
\text { Resolving } \\
\text { problems Data } \\
\text { communication }\end{array}$ & $\begin{array}{l}\text { Doing Experiment, } \\
\text { simulation,material } \\
\text { classification, } \\
\text { discussion, } \\
\text { brainstorming, } \\
\text { observation. } \\
\text { Scientific and } \\
\text { inquiry and/or } \\
\text { discovery or } \\
\text { (project-based } \\
\text { learning) } \\
\text { approaches }\end{array}$ & $\begin{array}{l}\text { Iqra, hiwar, } \\
\text { amtsal, targhib } \\
\text { and tarhib, } \\
\text { giving a good } \\
\text { example } \\
\text { (confirmative), } \\
\text { embedding } \\
\text { moral and } \\
\text { character. }\end{array}$ \\
\hline Closing & $\begin{array}{l}\text { Consolidation } \\
\text { Evaluasi }\end{array}$ & $\begin{array}{l}\text { Application } \\
\text { concept, } \\
\text { Reflection and } \\
\text { feedback, } \\
\text { Evaluation }\end{array}$ & $\begin{array}{l}\text { Targhib\& } \\
\text { tarhib } \\
\text { Iqra }\end{array}$ \\
\hline
\end{tabular}

3.3 Teacher candidate students' ability in integrating Islamic values and biology materials at senior high school level. The ability to 
integrate Islamic values in biology materials is an early indicator for being able to develop lesson plans. Biology materials are adapted to the competency standards of the graduates and the basic competencies of senior high school students. The determination of Islamic values and the characters that are supposed to be arranged at this stage.

Teacher candidate students' ability in integrating Islamic values and biology materials can be explained in table 2 below.

Table 2. Teacher candidate students' ability in integrating Islamic values and biology materials

\begin{tabular}{|c|c|c|}
\hline Ability indicators & $\begin{array}{l}\text { Average } \\
\text { score }\end{array}$ & Note \\
\hline $\begin{array}{l}\text { Write down the } \\
\text { indicators of learning } \\
\text { achievement } \\
\text { competencies based on } \\
\text { competency standards, } \\
\text { core competency } \\
\text { graduates and basic } \\
\text { competencies }\end{array}$ & 201.0 & Capable \\
\hline 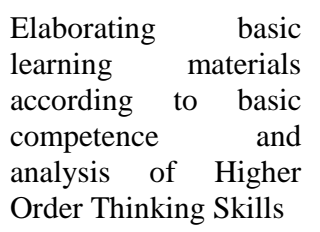 & 195.0 & Capable \\
\hline $\begin{array}{l}\text { Integrating Islamic } \\
\text { value in accordance } \\
\text { with the subject matter } \\
\text { and providing the } \\
\text { analysis of Higher } \\
\text { Order Thinking Skills }\end{array}$ & 192.0 & Capable \\
\hline $\begin{array}{l}\text { Designing scientific } \\
\text { approach in the } \\
\text { learning activity }\end{array}$ & 188.0 & Capable \\
\hline $\begin{array}{l}\text { Write down the syntax } \\
\text { and description of } \\
\text { learning activities } \\
\text { according to the } \\
\text { scientific approach }\end{array}$ & 188.5 & Capable \\
\hline $\begin{array}{l}\text { Develop a scoring plan } \\
\text { framework }\end{array}$ & 171.0 & Capable \\
\hline $\begin{array}{l}\text { Determining the } \\
\text { method of inculcating } \\
\text { Islamic values (iqro, } \\
\text { hiwar, amtsal, targhib } \\
\text { \& tarhib, keteladanan) }\end{array}$ & 160.0 & Capable \\
\hline $\begin{array}{l}\text { Describe the moral } \\
\text { values analogous to } \\
\text { Islamic Values }\end{array}$ & 143.5 & $\begin{array}{c}\text { Capable } \\
\text { enough }\end{array}$ \\
\hline
\end{tabular}

The average students' ability score in integrating the value of Islam on biology material 179.8 can be describe as capable categories.

3.4 The ability of teacher candidates plan the implementation of biology learning that integrates the Islamic values with a scientific approach.

Table 3. The ability of teacher candidates to plan the implementation of biology learning

\begin{tabular}{|c|c|c|}
\hline Ability indicators & $\begin{array}{c}\text { Average } \\
\text { score }\end{array}$ & Note \\
\hline $\begin{array}{l}\text { Arranging identity of } \\
\text { the subjects }\end{array}$ & 201.0 & Capable \\
\hline $\begin{array}{l}\text { Arranging core } \\
\text { competencies and basic } \\
\text { competencies }\end{array}$ & 201.0 & Capable \\
\hline $\begin{array}{l}\text { Formulate indicators of } \\
\text { achievement of } \\
\text { competence according } \\
\text { to the aspect of Islamic } \\
\text { values that encourage } \\
\text { students to analyze the } \\
\text { meaning of Islamic } \\
\text { values }\end{array}$ & 175.0 & Capable \\
\hline $\begin{array}{l}\text { Formulate the } \\
\text { objectives of learning } \\
\text { and achievement of } \\
\text { integration Islamic } \\
\text { values as indicated by } \\
\text { the expected method of } \\
\text { inculcating Islamic } \\
\text { value }\end{array}$ & 175.8 & Capable \\
\hline $\begin{array}{l}\text { The determination of } \\
\text { integrated teaching } \\
\text { materials and Islamic } \\
\text { values }\end{array}$ & 192.0 & Capable \\
\hline $\begin{array}{l}\text { Choosing learning } \\
\text { resources }\end{array}$ & 187.6 & Capable \\
\hline $\begin{array}{l}\text { Choosing learning } \\
\text { media }\end{array}$ & 179.0 & Capable \\
\hline $\begin{array}{l}\text { Determining the } \\
\text { learning model }\end{array}$ & 185.4 & Capable \\
\hline $\begin{array}{l}\text { Determingin leraning } \\
\text { methods }\end{array}$ & 187.0 & Capable \\
\hline $\begin{array}{l}\text { Develop learning } \\
\text { scenarios that integrate } \\
\text { the value of Islam in the } \\
\text { step of learning } \\
\text { activities with a } \\
\text { scientific approach }\end{array}$ & 192.8 & Capable \\
\hline $\begin{array}{l}\text { Designing learning } \\
\text { assessment, integration } \\
\text { of Islamic values } \\
\text { according to indicators } \\
\text { and learning objectives }\end{array}$ & 158.0 & Capable \\
\hline
\end{tabular}




\section{Conclusion}

The design of the biology learning course that is integrated to Islamic values is able to help the students' ability in developing the lesson plan of integrated biology and Islamic values with capability categories of 161 in category ranges from the range 156.3-201. The ability to arrange the implementation lesson plan begins with the ability to integrate the Islamic values in the biology material that will be taught, the category score of 179.8 in range of capable categories of 156.3-201.

\section{References}

Creswell, J.W.\&Clark, V.L.P. (2007) Designing and conducting mixed method research London: Sage Publ.

Guessoum, N. (2008). The Qur'an, science, and the (related) contemporary Muslim discourse Zygon 43(2) 411-431.

Hadjar, I., (2014). Dasar-Dasar Statistik Untuk Ilmu Pendidikan, Sosial \& Humaniora Pustaka Zaman. 66.

Hadjar, I., (2014). Dasar-Dasar Statistik Untuk Ilmu Pendidikan, Sosial \& Humaniora Pustaka Zaman. 66.

Huda, M., Kartanegara, M. (2015). Islamic Spiritual Character Values of al-Zarnj's Ta'Im al-Muta'allim. Mediterranean. Journal of Social Sciences 6 (4) 2039-9340.

Husamah \& Yuni P. (2014). Cooperative Learning STAD-PJBL:Motivation Thinking Skills, And Learning Outcomes of Biology Departement Students International. Journal of Eductaion Learning and Development 2(1), pp.77-94.

K.I. Supardi. (2017). Pembelajaran Kimia Terintegrasi Karakter Religius UNNES Press ISBN 978-602-285-093-9. 9.

Lickona, T. (2009). Eleven Principles of Effective Character Education. Journal of Moral Education. (25). 93-100.
Listyono, K.I. Supardi, Saeful, R, Nathan, H., (2018). Methods of integrating Islamic values in teaching biology for shaping attitude and character International Conference on Mathematics, Science and Education ICMSE 2017.

Ray, I.\& Chris, B. (2008). Systemic environmental decision making: designing learning systems. Kybernetes, 36 Issue: 9/10. 1340-1361.

Rehaf, A.M. (2016). Islamization of Science International. Journal of Islamic Thought ISSN 2232-1314 Vol. 9(6).

Reigeluth, C.M., (2009). Intructional Design Theories \& Models. NewYork: Taylor \& Francis.

Rochman C. 2010. Pembelajaran Fisika Berbasis Agama Islam di Perguruan Tinggi. Jurnal Penelitian Pendidikan 11(2).

Peraturan Menteri Pendidikan Dan Kebudayaan Republik Indonesia No 22 Tahun 2016 Tentang Standar Proses Pendidikan Dasar Dan Menengah.

Saiful, R \& Andin, I. (2012). Pengembangan Nilai Karakter Konservasi Berbasis Pembelajaran. Jurnal Penelitian Pendidikan 29 (2).

Sarah, Q. (2010). Feeding forward: using feedback to promote student reflection \& Learning a teaching model Innovation In Education And Teaching International Journal Vol 47.

The Holy Quran. (2013). King Saud University Electronic Moshaf Project. pp 215.

Winter, D.G. (2010) Allport's life and Allport's psychology. Journal of Personality. 65(3) 723-731.

Yeung, C.L. (2016). Blended Learning for Building Student-Teachers' Capacity to Learn and Teach Science-Related Interdisciplinary Subjects. Asian Association of Open Universities Journal 11(2). 